\title{
Kualitas Fisik Daging Sapi Peranakan Ongole dengan Pemberian Asam Askorbat dan Penyimpanan pada Suhu $5^{\circ} \mathrm{C}$
}

\author{
E.P. Samodra dan H. Cahyono \\ Jurusan Peternakan, Fakultas Pertanian Universitas Mercu Buana, Yogyakarta
}

\begin{abstract}
ABSTRAK
Penelitian bertujuan untuk mengetahui kualitas fisik daging sapi peranakan ongole (PO) yang diawetkan dengan asam askorbat dan disimpan dalam ruangan bersuhu $5^{\mathrm{O}} \mathrm{C}$. Penelitian dilakukan dengan Rancangan Acak Lengkap dengan pola faktorial 3 x 3. Faktor pertama asam askorbat ( $0 \%, 0,5 \%, 1 \%)$ dan faktor kedua lama penyimpanan (0, 5 dan 6 hari). Variabel yang diamati meliputi keempukan, cooking loss, water holding capacity dan $\mathrm{pH}$. Data dianalisis dengan analisis variansi dan perbedaan yang terjadi diuji lanjut berganda. Keempukan menunjukkan perbedaan yang tidak nyata untuk asam askorbat dengan kisaran $1,60-1,62 \mathrm{~kg} / \mathrm{cm}^{2}$; sedangkan lama penyimpanan menunjukkan kenaikan keempukan secara nyata berkisar $1,83-1,38 \mathrm{~kg} / \mathrm{cm}^{2}$. Rerata cooking loss menunjukkan perbedaan yang tidak nyata untuk asam askorbat (43,33 44,89\%); sedangkan untuk lama penyimpanan menunjukkan peningkatan yang nyata (40,00 47,00\%). Water holding capacity menunjukkan perbedaan yang tidak nyata untuk asam askorbat (32,88 - 33,65\%); tetapi lama penyimpanan menunjukkan penurunan yang nyata (34,61 - 32,32\%). Rerata $\mathrm{pH}$ menunjukkan perbedaan yang tidak nyata untuk asam askorbat $(5,99-6,16)$; dan terjadi penurunan secara nyata untuk penyimpanan yang semakin lama $(6,43-5,84)$. Disimpulkan bahwa pemberian asam askorbat sampai $1 \%$ tidak mempengaruhi kualitas fisik daging, sedangkan semakin lama penyimpanan menurunkan kualitas daging $(\mathrm{p}<0,05)$.
\end{abstract}

Kata kunci : Daging sapi PO, asam askorbat, lama penyimpanan

\section{Physical Quality of Beef Cattle as Affected by Ascorbic Acid Addition and Storage Duration at $5^{0} \mathrm{C}$}

\begin{abstract}
The research was conducted to investigate the effect of soaking meat of Peranakan Ongole cattle with ascorbic acid and storage duration at $5^{\circ} \mathrm{C}$ on physical quality of meat. The experiment was done in Complete Randomised Design by factorial $3 \times 3$. First factor was ascorbic acid with 3 levels $(0 \%, 5 \%, 1 \%)$, and second factor is storage duration with 3 levels $(0,5$, and 6 days). Variables that were measured: tenderness, cooking loss, water holding capacity and $\mathrm{pH}$. Data were analyzed by variance analysis and the significant result were tested by Duncan's test. Tenderness average for ascorbic acid ranging between $1,60-1,62 \mathrm{~kg} / \mathrm{cm}^{2}$, and for storage duration was increased from 1,83 to $1,38 \mathrm{~kg} / \mathrm{cm}^{2}$. Cooking loss average for ascorbat acid ranged from 43,33 to $44,89 \%$, and for storage duration increased from 40,00 to 47,00\%. Water holding capacity average for ascorbic acid ranging between 32,88 - 33,65\%, but for storage duration decreased from 34,61 to 32,32\%. The $\mathrm{pH}$ average for ascorbic acid ranging from 5,99 to 6,16, and increased for storage duration from 6,43 to 5,84. It can be concluded that physical quality of beef cattle was not affected bay ascorbic acid up to $1 \%$, but was significantly decreased by storage duration $(p<0,05)$.
\end{abstract}

Key words: Pernakan Ongole meat, ascorbat acid, storage time 


\section{PENDAHULUAN}

Daging merupakan sumber protein hewani yang sangat sangat dibutuhkan tubuh manusia. Dari berbagai sumber protein hewani, daging sapi merupakan daging yang menduduki peringkat atas daripada daging dari ternak lain, baik dari segi kualitas maupun tingkat kesukaan. Sejalan dengan pertambahan penduduk Indonesia yang sudah mencapai 220 juta lebih pada awal tahun 2006, kebutuhan daging juga semakin meningkat meskipun konsumsi protein hewani belum memenuhi standart minimal FAO. Konsumsi protein hewani yang berasal dari daging saat ini baru mencapai 4,93 g/kapitsa/hari, sementara anjuran FAO sebesar 5,5 g/kapita/hari (Anonim, 2003). Sebagai bahan sumber protein, daging mengandung kadar air yang tinggi, derajad keasaman yang sesuai untuk pertumbuhan mikroorganisme (Frazier, 1967; Roman dan Ziegler, 1974), sehingga daging daging sangat mudah rusak (Suparno et al., 1988). Untuk mengatasi hal tersebut diperlukan pengawetan agar diperoleh daging dengan kualitas tetap terjamin.

Pengawetan yang umumnya dilakukan adalah dengan pengontrolan duhu lingkungan, penurunan kadar air daging, dan penggunaan bahan pengawet kimiawi (Lawrei, 1979). Kerusakan daging dimulai dari oksidasilemak dari udara luar. Oksidasi ini menyebabkan bau dan citarasa yang tidak disukai oranga pada waktu dimasak (Ardani dan Djoemantoro, 1979). Salah satu cara untuk mengurangi proses oksidasi lemak daging yaitu dengan pencelupan daging tersebut ke dalam asam askorbat. Hal ini dilakukan sehubungan dengan fungsi asam askorbat sebagai anti oksidan yang dapat menghambat oksidasi lemak dan mencegah kerusakan protein (Lawrei, 1979) dan sebagai pembentuk rasa dan warna daging, mudah dideteksi, aman, dan mudah didapatkan (Parman dan Salinard, 1967). Di sisi lain, mikroorganisme dan bakteri pembusuk mudah berkembang dalam suhu kamar. Proses transportasi daging dari tempat pemotongan sampai konsumen membutuhkan waktu, bahkan bertambah lama jika memerlukan pengiriman yang jauh dalam jumlah yang banyak. Pertambahan waktu tersebut akan memberikan kesempatan mikroorganisme dan bakteri untuk berkembang biak. Penyimpanan daging dalam suhu yang rendah memungkinkan perkembangan mikroorganisme maupun bakteri dapat diperlambat.

Berdasarkan hal tersebut perlu dilakukan pengkajian mengenai kualitas fisik daging sapi yang disimpan pada suhu rendah setelah dicelupkan dalam asam askorbat. Sampai waktu berapa lama daging dapat bertahan kualitasnya. Kualitas fisik tersebut meliputi keempukan (tenderness), susut masak (Cooking Loss), daya ikat air (Water Holding Capacity), dan pH. Melalui penelitian ini diharapkan diperoleh hasil yang dapat diaplikasikan oleh masyarakat dalam pengelolaan daging.

\section{MATERI DAN METODE}

Penelitian ini dilaksanakan di Laboratorium Peternakan dan Laboratorium Kimia Universitas Wangsa Manggala Yogyakarta. Digunakan 2,7 kg daging paha dari 3 ekor sapi PO (masing-masing 0,9 kg), asam askorbat, aquadest, dan reagen eber (dietil eter : $\mathrm{HCl}$ pekat : alkohol 79\%=1:1:3).

Digunakan alat bantu penelitian: beban, plat kaca, kertas saring, kertas grafik, kertas hisap, pHmeter, pisau, timbangan, water bath, termometer, kulkas, mistar, dan tabung reaksi.

Penelitian dengan bantuan metode eksperimental dalam Rancangan Acak Lengkap melalui pola faktorial $3 \times 3$. Faktor pertama persentase asam askorbat dengan 3 level ( $0 \%$, $0,5 \%$, 1\%), dan faktor kedua lama penyimpanan dengan 3 level (0, 5 dan 6 hari). Setiap perlakuan diulang 3 kali. Variabel yang diamati meliputi keempukan, cooking loss, water holding capacity, dan $\mathrm{pH}$.

Uji keempukan dan cooking loss dilakukan dengan metode Bouton. Water holding capacity diuji menurut cara Hamm, pengukuran $\mathrm{pH}$ menurut cara Bouton (sitasi Suparno, 1992) dan kerusakan daging diukur 
melalui uji eber. Data dianalisis dengan analisis variansi dan perbedaan yang terjadi diuji lanjut berganda Duncan.

\section{HASIL DAN PEMBAHASAN}

\section{Keempukan}

Nilai rerata keempukan daging sapi dengan perlakuan asam askorbat menunjukkan perbedaan yang tidak nyata dengan kisaran nilai $1,60-1,62 \mathrm{~kg} / \mathrm{cm}^{2}$, sedangkan untuk perlakuan lama penyimpanan menunjukkan penurunan keempukan secara nyata berkisar $1,83-1,38 \mathrm{~kg} / \mathrm{cm}^{2}(\mathrm{p}<0,05)$. Nilai keempukan selengkapnya pada Tabel 1 .

Keempukan daging dipengaruhi faktor antemortem (genetik, umur, jenis kelamin, stress, aktivitas) dan faktor postmortem (pelayuan, pembekuan, metode pengolahan), (Bouton et al., 1975). Asam askorbat bersifat melapisi daging dari pengaruh luar (udara dan air) dan tidak berproses dalam daging.

Nilai keempukan semakin menurun sejalan dengan pertambahan lama simpan. Artinya bahwa daging semakin empuk. Hal tersebut diduga bahwa dalam daging terjadi penguraian protein selama penyimpanan, sehingga ikatan kolagen menjadi longgar.
Forrest et al., (1976) menyatakan bahwa daging akan mengalami penguraian protein dan pemecahan ikatan kolagen selama penyimpanan. Penguraian tersebut dapat disebabkan oleh mikroorganisme yang sempat mengkontaminasi daging sebelum daging masuk di ruang pendingin.

\section{Cooking Loss}

Nilai rerata cooking loss daging sapi dengan perlakuan asam askorbat menunjukkan perbedaan yang tidak nyata dengan kisaran nilai 43,33 - 44,89\%; sedangkan untuk perlakuan lama penyimpanan menunjukkan kenaikan cooking loss secara nyata berkisar $40,00-47,00 \%(\mathrm{p}<0,05)$. Nilai cooking loss selengkapnya pada Tabel 2.

Bouton et al. (1975) menyatakan bahwa nilai susut masak dapat dipengaruhi oleh $\mathrm{pH}$, serabut otot, status kontraksi miofibril, ukuran dan bobot sampel, dan penampang lintang daging. Asam askorbat belum berpengaruh secara nyata terhadap cooking loss daging diduga karena sifatnya sebagai antioksidan tidak dapat mempengaruhi perubahanperubahan kimiawi dan fisis daging. Air yang keluar dari daging tidak dapat dicegah oleh asam askorbat.

Tabel 1. Rerata nilai keempukan daging sapi PO $\left(\mathrm{kg} / \mathrm{cm}^{2}\right)$.

\begin{tabular}{ccccc}
\hline \hline \multirow{2}{*}{$\begin{array}{c}\text { Lama simpan } \\
\text { (hari) }\end{array}$} & \multicolumn{3}{c}{ Asam askorbat (\%) } & Rerata \\
\cline { 2 - 4 } & 1,88 & 0,5 & 1 & \\
\hline 0 & 1,61 & 1,82 & 1,79 & $1,83^{\mathbf{a}}$ \\
5 & 1,31 & 1,62 & 1,62 & $1,62^{\mathbf{b}}$ \\
6 & 1,60 & 1,40 & 1,40 & $1,38^{\mathbf{c}}$ \\
\hline Rerata & 1,61 & 1,62 & - \\
\hline a,b,c Superskrip yang berbeda pada rerata menunjukkan perbedaan yang nyata.
\end{tabular}

Tabel 2. Rerata nilai cooking loss daging sapi PO (\%).

\begin{tabular}{ccccc}
\hline \hline \multirow{2}{*}{$\begin{array}{c}\text { Lama simpan } \\
\text { (hari) }\end{array}$} & \multicolumn{3}{c}{ Asam askorbat (\%) } & Rerata \\
\cline { 2 - 4 } & 0 & 0,5 & 1 & \\
\hline 0 & 40,00 & 39,33 & 40,67 & $40,00^{\mathbf{a}}$ \\
5 & 46,00 & 44,00 & 44,67 & $44,89^{\mathbf{b}}$ \\
6 & 44,67 & 46,67 & 44,00 & $47,00^{\mathbf{c}}$ \\
\hline Rerata & 44,89 & 43,33 & 44,00 & - \\
\hline
\end{tabular}

$\overline{a, b, c}$ Superskrip yang berbeda pada rerata menunjukkan perbedaan yang nyata. 
Pengeluaran air selama penyimpanan tidak dapat dicegah, sebaliknya air tidak dapat diserap/masuk kembali. Pertambahan lama simpan akan memperbanyak cairan yang keluar. Hal ini akan mengakibatkan cooking loss daging semakin tinggi. Peningkatan nilai susut masak mengindikasikan penurunan kualitas daging. Menurut Suparno (1994), penyimpanan yang semakin lama menyebabkan peningkatan nilai susut masak, karena cairan yang keluar tidak dapat diserap kembali oleh serabut otot. Bersamaan dengan pengeluaran cairan, maka nutrien dalam daging ikut keluar. Nilai cooking loss yang tinggi menandakan ikatan protein lemah, sehingga kemampuan mengikat cairan daging lemah (Hamm, 1964; Bouton et al., 1975).

\section{Water Holding Capacity}

Nilai rerata water holding capacity dengan perlakuan asam askorbat menunjukkan perbedaan yang tidak nyata dengan kisaran nilai 32,88 - 33,65\%; sedangkan untuk perlakuan lama penyimpanan menunjukkan penurunan water holding capacity secara nyata berkisar 34,61-32,32 \% ( $<<0,05)$. Nilai water holding capacity selengkapnya pada tabel 3.
Daya ikat air daging dipengaruhi oleh temperatur, kelembaban, penyimpanan, umur ternak, lemak intramuskuler (Hamm, 1964). Perendaman daging dalam asam askorbat selama 3 menit diduga belum menyebabkan penetrasi dalam daging secara penuh. Disisi lain diduga bahwa dengan pertambahan waktu simpan akan terjadi peningkatan degradasi protein dan kolagen yang menyusun ikatan silang antar serat daging. Hal ini menyebabkan penurunan fungsi protein dalam mempertahankan air daging. Bucle (1985) menyatakan bahwa daya ikat air daging cenderung menurun karena protein sarkoplasma otot sangat mudah rusak dalam suasanya asam. Hamm (1964) mengungkapkan bahwa penyimpanan yang terlalu lama akan menurunkan daya ikat air dan mengakibatkan perubahan struktur protein daging.

\section{Nilai pH}

Nilai rerata pH daging (Tabel 4) dengan perlakuan asam askorbat menunjukkan perbedaan yang tidak nyata dengan kisaran nilai 5,99 - 6,16; sedangkan untuk perlakuan lama penyimpanan menunjukkan penurunan $\mathrm{pH}$ secara nyata berkisar $6,43-5,84(\mathrm{p}<0,05)$.

Tabel 3. Rerata nilai water holding capacity daging sapi PO (\%).

\begin{tabular}{ccccc}
\hline \hline \multirow{2}{*}{$\begin{array}{c}\text { Lama simpan } \\
\text { (hari) }\end{array}$} & \multicolumn{3}{c}{ Asam askorbat (\%) } & Rerata \\
\cline { 2 - 4 } & 0 & 0,5 & 1 & \\
\hline 0 & 34,76 & 34,36 & 34,70 & $341^{\mathbf{a}}$ \\
5 & 33,71 & 32,60 & 32,11 & $32,81^{\mathbf{b}}$ \\
6 & 32,48 & 32,64 & 32,17 & $32,32^{\mathbf{c}}$ \\
\hline Rerata & 33,65 & 33,20 & 32,88 & - \\
\hline a,b,c Superskrip yang berbeda pada rerata menunjukkan perbedaan yang nyata.
\end{tabular}

Tabel 4. Rerata nilai pH daging sapi PO.

\begin{tabular}{ccccc}
\hline \hline \multirow{2}{*}{$\begin{array}{c}\text { Lama simpan } \\
\text { (hari) }\end{array}$} & 0 & 0,5 & Rerata \\
\cline { 2 - 4 } & 6,50 & 6,30 & 6,23 & $6,43^{\mathbf{a}}$ \\
5 & 6,17 & 5,93 & 5,90 & $6,00^{\mathbf{b}}$ \\
6 & 5,83 & 5,87 & 5,83 & $5,84^{\mathbf{c}}$ \\
\hline Rerata & 6,16 & 6,03 & 5,99 & \\
\hline a,b,c Superskrip yang berbeda pada rerata menunjukkan perbedaan yang nyata.
\end{tabular}


Tabel 5. Hasil uji Eber

\begin{tabular}{cccc}
\hline \hline $\begin{array}{c}\text { Lama simpan } \\
\text { (hari) }\end{array}$ & Asam askorbat (\%) & \\
\cline { 2 - 4 } & 0 & 0,5 & 1 \\
\hline 6 & $\mathrm{r}$ & $\mathrm{b}$ & $\mathrm{b}$ \\
8 & - & $\mathrm{b}$ & $\mathrm{b}$ \\
\hline
\end{tabular}

Keterangan: $\mathrm{r}=$ rusak $\quad \mathrm{b}=$ baik $\quad-=$ tidak diuji

Bouton et al. (1975) menyatakan bahwa faktor yang mempengaruhi $\mathrm{pH}$ adalah stres ternak sebelum dipotong, pemberian injeksi hormaon, species, macam otot, dan aktivitas enzim yang mempengaruhi glikolisis. Perbedaan persentase asam askorbat tidak mempengaruhi nilai $\mathrm{pH}$ karena faktor-faktor intrinsik postmortem tidak dapat dipengaruhi oleh asam askorbat tersebut.

Pertambahan lama waktu simpan menyebabkan perubahan-perubahan fisis dan kimiawi daging, kesempatan tumbuh mikroorganisme dan jamur bertambah. Bersamaan dengan peristiwa tersebut menyebabkan perubahan nilai $\mathrm{pH}$ secara nyata. Weiser et al. (1971) menyatakan bahwa perubahan asam bermula dari jamur dalam daging yang memecah protein menjadi asam amino sehingga kadar asam daging semakin tinggi atau nilai $\mathrm{pH}$ menurun.

\section{Uji Eber}

Kerusakan daging mulai terjadi pada hari ke 6 penyimpanan untuk $0 \%$ asam askorbat. Untuk persentase 0,5 dan $1 \%$ terjadi pembusukan pada hari ke 8. Pemberian asam askorbat dapat sedikit mempertahankan kondisi daging. Lawrie (1979) mengungkapkan bahwa asam askorbat berfungsi sebagai antioksidan, yakni menghambat oksidasi lemak dan menghambat kerusakan protein. Hasil uji eber tertera pada tabel 5.

Pada kondisi suhu penyimpanan 5 OC memungkinkan mikroorganisme pembusuk masih dapat tumbuh. Karena pertumbuhan bakteria, protein terdegradasi dan menimbulkan gas amonia (NH3) dan kerusakan daging.

\section{KESIMPULAN}

Pemberian asam askorbat sampai 1\% tidak mempengaruhi kualitas fisik daging, sedangkan semakin lama penyimpanan akan terjadi penurunan kualitas daging secara nyata $(\mathrm{p}<0,05)$. Penyimpanan daging tidak terlalu lama ( $<5$ hari) atau pada suhu simpan dibawah temperatur hidup mikroorganisme.

\section{DAFTAR PUSTAKA}

Adnan, A.S., 1977. Tinjauan Umum Tentang Daging dan Masalahnya. Lembaga Penelitian Peternakan. Bogor.

Ardani, A. dan Djoemantoro, 1979. Penentuan Bilangan Atsiri Untuk Menguji Adanya Kerusakan Bahan Makanan Hewan Karena Proses Oksidasi Lemak. Buletin Biokimia. Bogor. No. 9.

Buckle, K.A. Edwards, G.H. Fleet and Nwooton, 1985. Ilmu Pangan. Universitas Indonesia Press, Jakarta.

Bouton, P.E., P.V. Harris and W.R. Shorthose, 1975. Changes in Shear Parameter of Meat Assosiated With Structural Changes Produced By Aging Cooking and Myofibrilar Contraction. J. Food Sci. 40:1107.

Bouton, P.E. 1976. Factors Influencing Cooking Losses From Meat. J. Food Sci. 40:1092.

Forest, I.C., I.D. Aberle, H.B. Hendrick, M.D. Judge and R.A. Merleel, 1975. Principles of Meat Science. W.H. Freman and Co. San Fransisco.

Frazier, W.C., 1967. Food Microbiology. $2^{\text {nd }}$ ed. Mc. Grow Hill Book. Co. New York.

Hamm, R., 1964. The Water Holding Capacity of Meat pada Techniques for Measuring Some 
Quality Characteristic of Meat. D.E. Tribe ed Crico, Melbourne.

Jay, J.M. and L.A Shelef, 1978. Microbia Modification in raw and Processed Meat and Poultry at Low Temperatures. Food Technol. 37:186 - 187.

Lawrie, R.A. 1979. Meat Science. $3^{\text {rd }}$ ed. Pergamon Press. Oxford.

Miller, A.R., 1963. Meat Hygine. $2^{\text {nd }}$ ed. Lea and Febiger. Philadelpia.

Palupi, W.D.E., 1986. Tinjauan Literatur Pengolahan Daging. Pusat Dokumentasi Ilmiah Nasional. LIPI. Jakarta.

Priyanto, G., 1988. Tehnik Pengawetan Pangan. Proyek Pengembangan Perguruan Tinggi, UGM. Yogyakarta.

Romans, J.R. and Ziegler, 1974. The Meat We Eat. $10^{\text {th }}$ ed. The Interstete Printers and Publ. Denville, Illionis.
Sachkeim, G.I. and D.D. Lehman, 1981. Chemistry for The Health. Science. $4^{\text {th }}$ ed. Macmillan Publ. Co., New York.

Suparno, 1988. Komposisi Karkas dan Teknologi Daging. Fakultas Peternakan. Gadjah Mada University Press. Yogyakarta.

Suparno, 1994. Ilmu dan Teknologi Daging. Fakultas Peternakan. Gadjah Mada University Press. Yogyakarta.

Sosroamidjojo, 1984. Ternak Potong dan Kerja untuk Sapi Potong. CV. Yasa Guna. Jakarta.

Weiser, H.H., G.J. Mountrey and W.A. Gould, 1971. Practicial Food Nicrobiology and Technology. $2^{\text {nd }}$ ed. The Avi Publ, Co. West Port. Connecticut.

Winarno, F.G. dan B.S.L. Jenie, 1983. Kerusakan Bahan Pangan dan Cara Pencegahannya. Ghalia Indonesia kerjasama Pusat Penelitian dan Pengembangan Pangan, IPB. Bogor.

Winarno, F.G., 1984. Kimia Pangan dan Gizi. Gramedia. Jakarta. 